\title{
A FACTORIAL ANALYSIS OF INFORMACION SOURCES THAT INFLUENCE UNIVERSITY CHOICE IN ALBANIA
}

\author{
Elfrida Manoku ${ }^{1}$
}

\begin{abstract}
These days Higher Education Institutions (HEIs) in Albania are operating in a highly dynamic environment. The aim of this study is to examine the sources of information that influence the student's selection between public or private university in Albania by identifying the role of marketing communication in this selection. The data was gathered through self-administered questionnaires in 17 public and private universities throughout Albania. The factorial analysis conducted using the evaluations from 28 different sources of information, concluded that mainly four factors influenced university choice. These were, public relations, advertising, reference groups and internet marketing. Most of the Albanian Universities need a better understanding of the entire process the prospective students undergo during their university selection process. They also should try adopting a new orientation in their marketing communication strategies based on the students' need for information.
\end{abstract}

JEL Classification Number: M31, DOI: http://dx.doi.org/10.12955/cbup.v4.765

Keywords: university choice, marketing communications, students, higher education institutions.

\section{Introduction}

Higher education has undergone important changes worldwide documented by a large number of studies in this field. As in other countries, higher education in Albania over the past 25 years is characterized by changes in structure, form and content, adapting to the changes that have occurred in the Albanian society and moving towards unification with countries in the near-by region and Europe. The need for marketing and its elements have felt mostly by private HEIs, which emerged in the early 2000 s and have grown significantly not only in their capacity and programs of study, but also improved their image. Public HEIs for a long time have not felt the need to adjust to the rules of the market. Due to the high reputation they enjoyed the higher demand by students to study in these institutions.

Currently, there are 15 public HEIs and 26 non-public HEIs. However, in recent years competition from private HEIs in the region and beyond is becoming evident. These institutions are intensively trying to attract the best students with scholarship programs and offers, thus the students view them as better alternatives for study. The amendments to the law on higher education aimed to give universities more autonomy, which highlighted the need for orientation of their students and provision of a superior value for them.

The Albanian students now have much more chances to choose where to study, whether abroad or at home, or whether in public or private universities. Administrators of Albanian universities should know and understand how students make their choices about where are they going to study, as well as factors affecting these choices so that they can adopt ways for attracting and retaining the students as well as adopt the service and communication strategies for them (Manoku, 2015). In order to adjust their marketing strategies HEIs should know how prospective students make their decisions during the selection process of the university, what information they consider useful, and from what groups or individuals they are influenced.

This paper is structured in 5 sections. The first section consisting of introduction is followed by a second section comprising of a short literature review and in the third section, the methodology of the study is described. The fourth section presents the main findings of the study through descriptive and factorial analysis and their interpretations. The last section provides the conclusions and some recommendations for the interest groups.

\section{Communication in education}

Kotler \& Keller (2012) classify the elements of marketing communication in different organizations as: advertising, public relations and publicity, personal selling, sales promotion, direct marketing,

\footnotetext{
${ }^{1}$ Elfrida Manoku, Lecturer at Marketing - Tourism Department, Faculty of Economics, University of Tirana, Albania, elfrida.manoku@gmail.com
} 
online communication and mobile and outdoors communication. Kotler \& Fox (1995) emphasized that educational institutions need an effective communication with the markets and their audiences. Communication involves an exchange between the institution and the audience. On the other hand Kotler \& Fox (1995), point out that the main forms of communication used by most higher education institutions are: public relations, advertising and marketing publications. Most educational institutions pay greater attention to public relations, marketing publications and a lower level to advertising than other elements.

According to Eiglier \& Langeard (1991), the intangibility of the service, which means that they can't be seen, touched or presented with pictures or drawings, poses a real challenge for a service company as it is not possible to show the service at any moment, but only the components of the service. However, service companies, besides the traditional means of communication, have two other available supports which are: personal contact (sends several messages to customers) and physical support (supplemented with signals to consumers). Similarly, institutions of higher education, as well as other organizations of service, have these tools of communication available, but according to Nicholls, Harris, Morgan, Clarke, and Sims (1995) the most common forms of communication for these institutions are public relations, personal contacts and advertising.

Steele (2008) studied how to build effective communication with students of colleges and universities using catalogs, application forms and material about the study programs such as brochures, posters, sponsorships and billboards, university websites, and advertisements on TV and newspapers, which are often the most used instruments of communication by the university (Yamamato, 2006).

Raposo and Alves (2007), in their empirical studies verified how informal information sources such as parents, friends, current students and teachers of the school were the most common sources of information for the students when seeking information about the university. Consequently, it is important not to overlook this information channel because if the information transmitted is positive, the institution can achieve very good marketing results, but when the information transmitted is negative, the institution may have a serious problem which can lead to a real aversion to the institution and can be difficult to change (Edmiston-Strasser, 2009).

Sshuller \& Rasticova (2011) analyzed the methods and styles of marketing communications of universities and their academic staff when communicating with prospective students. They identified the most effective means of marketing communications to attract the new students.

A lot of authors analyze information sources that students use during the process of seeking information, evaluation of alternatives and the final selection of the university. Several authors mention the influences that exercise websites and social networks (Facebook, Tweeter, Instagram, etc.) in the decision of prospective students (Yamamoto, 2006; Kim \& Gasman, 2011).

Another source is publications used by students. The rate of using publications gives high results in many studies despite the fact that many use website. In many studies, publications were identified as an important source of information during the evaluation of alternatives (Briggs, 2006; Hoyt \& Brown, 2003; Veloutsou, 2005; Sshuller \& Rasticova, 2011). Mass media such as television, newspapers and magazines are frequently used by universities for advertising (Kinzie \& Palmer, 2004; Sshuller \& Rasticova, 2011). In the literature, it is clearly shown that reference groups like sisters, brothers, friends, peers, high-school teachers, relatives and other individuals influence the HEI selection process of students. Some studies of Shanka, Quintal and Taylor (2005) examined the correlation between student's interaction with other students closely associated with the University and their enrollment in a particular university.

Influence on decision-making that comes from the family is shown in majority of studies on university selection. The family is seen as a strong financial influential as in most cases parents give the child financial support to pursue higher studies. Family is seen as an important source of information and it plays a role in forming expectations of future students and affect their beliefs. Kusumawati (2013) in his study noted that the financial support coming from family or parents could limit the choice of the university. Parents influence their children to study in a particular destination or a study program preferred by them since the parents sponsor the child's studies. Almost all of the university choice studies have identified reference groups as a strong influencing factor in the 
decision of students, and at the same time as an important source of reliable information. In literature review, to fulfill the study objective, the information sources were summarized in two groups which in total are 28 factors that will be measured about how much they influence the university choice of Albanian students.

Student information sources (marketing communications tools)

These include: website of the university/ faculty, social networks of university/faculty, advertising on radio, advertising in the press, advertising on television, advertising on the Internet, brochures and leaflets, posters, billboards, video presentation and information on the website, materials for new students, scientific conferences, scientific articles and articles in media of academic staff, the appearance in the media of experts and university academics, news about/from university, competitions organized by the university, different fairs organized by university, various university events, visits to the college/university, and open days.

\section{Reference groups}

These include: parents, siblings, peers, relatives, high-school teachers, career offices, students studying in this college or graduated from it, and faculty staff.

\section{Methodology}

In order to get a better understanding about the sources of information that influenced most of the Albanian student's choice, a factor analysis method was considered most appropriate.

This study is part of a bigger study that was conducted by me during 2015 in order to analyze all factors than influence university choice of Albanian students The data collection method was the survey through questionnaire consisting of close ended questions. There were 17 Albanian HEIs involved in the study, where 10 were public universities, 4 were non-public universities and 3 were non-public higher education schools (Manoku, 2015).

The population targeted in meeting the study's objectives were the freshmen students of both public and private universities (Manoku, 2015).

The procedure for selection of the sample was the stratification method and random selection of the groups which had classes a certain day, therefore involving all the students of the group. The selection was made randomly but it was ensured a coverage and representation of as many majors (subjects) as possible within departments.

The students were asked to choose a Likert ascending scale from 1-5 about how much the source of information affected their choices for the university ( 1 - none, 2 - a little, 3 - somewhat, 4 - very much, 5 - extremely) (Manoku, 2015).

Data were processed with SPSS20 and Excel.

\section{Analysis and interpretation of results: Factorial analysis for student's information sources}

A factor analysis was conducted using the evaluation of the importance of different sources of information. First, tests were carried out to check adequacy of the data for factor analysis. Specifically, the anti-image matrix was examined, all the coefficients of its main diagonal resulted large enough (ranking 0.89 - 0.96) and elements outside the diagonal were sufficiently small. So this matrix recommended that all variables are suitable for inclusion in the analysis.

Secondly, Kaiser-Myer-Olkin (KMO) test and Bartlett's test of sphericity were performed. Generally, KMO gets values between 0 and 1, but there was an agreement between the researchers that it's value should be above 0.6. Bartlett's test of sphericity tested the zero hypothesis that the correlations matrix was a unit matrix, thus, the elements of the main diagonal were 1 and those outside it are 0 .

The findings of these tests are presented in Table 1 below and based on the criteria discussed for goodness of adjustment data for performing factor analysis we can say that our sample is very good. This guarantees reliable results of this analysis.

\section{Results}

There are several ways for selecting the adequate number of factors, such as taking Eigen values that should be higher than 1 and the Scree graph. 
Table 1: Kaiser-Meyer-Olkin measure and Bartlett's test of sphercity of sampling adequacy

\begin{tabular}{|lc|l|}
\hline Kaiser-Meyer-Olkin Measure of Sampling Adequacy. & 0.924 \\
Bartlett's Test of Sphericity & Approx. Chi-Square & 3710.963 \\
\hline & Df & 378 \\
\hline Sig. & 0.000 \\
\hline
\end{tabular}

Source: The author

Considering the fact that the essence of factorial analysis is to explain a large amount of variance of original variables by means of a smaller number of factors, attention should be given to the amount of explained variance. This amount is $66.4 \%$ and, the final solution of the factorial analysis was found to be 4 factors. In order to interpret the factors, the solution underwent Varimax rotation method. Eigen values, individual variances and the cumulative method of 4 factors resulting from the analysis are shown in Table 2.

Table 2: Total variance explained from common factors

\begin{tabular}{|l|l|l|l|}
\hline \multirow{2}{*}{ Factor } & \multicolumn{3}{|l|}{ Rotation Sums of Squared Loadings } \\
\cline { 2 - 4 } & Total & \% Of variance & \% Cumulative \\
\hline 1 & 7.212 & 25.757 & 25.757 \\
\hline 2 & 5.192 & 18.544 & 44.302 \\
\hline 3 & 3.660 & 13.072 & 57.374 \\
\hline 4 & 2.529 & 9.031 & 66.405 \\
\hline
\end{tabular}

Source: Author

To interpret the common factors, correlations should be studied as they determine the strength of relations. Factors can be identified from larger correlations, but it is important as to analyze the 0 and lower correlations as well in order to confirm the identification of factors (Gorsuch, 1983). Interpretation of factors includes information contained in each of the variables and their meaning is drawn after analyzing the coefficients of the higher correlation among the variables and each of the factors. The inferior limit of factor loading is 0.524 , which is a considerable figure.

The first factor explains a significant amount of the total variance of the variables included in the analysis, which is 25.76. It has high correlation coefficients with 11 of the original variables. Factor correlation coefficients are generally high. The highest amongst them is the variable "Scientific conferences", which is specifically 0.774 , followed by the correlation coefficient with the variable "various fairs organized by the university" which is 0.761 . In descending order, link with other variables are ranked as follows: "Scientific articles and articles in the media of academic staff" (0.760), "Competition organized by the university" (0.731), "Various university events"(0.714) "The appearance in the media of experts and university academics" (0.691), "Open days" (0.635), "Materials for new students" (0.633), "News about/from the university" (0 .587), "Video presentation and information on the website" (0 .581),"Visit to the college/university "0.559, "The staff of the faculty" (0.573), and "Career offices" (0 .652). These variables are measures of various elements related to public relations, hence this factor is termed as "Public relations".

The second component derived from factor analysis is strongly correlated with a set of variables, which represent different ads. Specifically, the coefficient of correlation of this component with the 
variable "Advertising on radio" is 0.808 , with "advertising in the press" is 0.813 , with "advertising on television" correlation is 0.707 , with "advertising on the Internet" is 0.524 , with "Brochures and leaflet" is 0.650 , and the "Posters" and "Billboards" correlation coefficients are 0.740 and 0.765 respectively. Clearly, this factor is termed "Advertising" and explains $18.54 \%$ of the total variance of the original variables included in the analysis.

The third factor explains $13.07 \%$ of the total variance. Variables that are more strongly associated with it are "Parents" and "Relatives", the correlation coefficients of which are 0.837 and 0.791 respectively. In the same vein, other variables are also associated with individuals who have influenced the university choice. According to the order of their correlation with this component of these variables are "Peers" (0.561), "Sisters and brothers" (0.739), "Secondary school teachers" (0 $.648)$ and "Students studying in this university or graduated in it"(0.618). Based on the characteristics of these variables, this factor is labeled "Reference groups".

The fourth factor has strong links with two of the variables included in the analysis. They are "website of the university / faculty," with a correlation coefficient of 0.758 , and "Social Networks of University/Faculty" with a correlation of 0.714 . This factor explains about $9 \%$ of the total variance and is labeled "Internet Marketing".

\section{Conclusions}

The factorial analysis of 28 information sources that correspond to marketing communication tools and reference groups reduced the number of factors in 4 main groups which influence the students' choice of a higher education institution in Albania. They were named: Public relations, advertising, reference groups and internet marketing. Research results highlight the need for a communication strategy geared to inform and attract new students. Students confirmed that information provided by Universities does not match their needs. The higher the quality of information provided, the more are the chances that a student make a realistic and reliable assessment of what is the best choice for them.

Albanian universities should adopt their marketing strategies, especially communication strategies with prospect students' needs and provide them with detailed information through websites, open days, leaflets, advertising in mass media or the internet. They should organize different public relations activities more often since they are regarded as more reliable by the Albanian students, and they pay more attention to word of mouth marketing because actual students influence the university choice of new students considerably and try to improve their institutional reputation in all public eyes.

\section{References}

Alves, H., \& Raposo, M. (2007). "Student satisfaction index in Portuguese public higher education". Service Industry Journal 27(6): 795-808.

Briggs, S. (2006). An exploratory study of the factors influencing undergraduate student choice: the case of higher education in Scotland. Studies in Higher Education, 31 (6), 705 - 722.

Edmiston-Strasser, D. (2009). "An examination of integrated marketing communication in U.S. public institutions of higher education". Journal of Marketing for Higher Education 19(2): 142-165.

Eiglier, P., \& Langeard, E. (1991). "Servaction, a gestão do marketing de empresas de serviços Servaction, the marketing management services companies]." McGraw-Hill, New York.

Gorsuch, R. (1983). Factor Analysis, Hillsdale, NJ: Erlbaum.

Hoyt, J. E., \& Brown, A. B. (2003). Identifying College choice Factors to successfully market your institutions. College and University, 78(4) 3-10.

Kim, J. K., \& Gasman, M. (2011). In search of a "good college": Decisions and determinants behind Asian American Students' college choice. Journal of College Students Development. 52(6), 706 - 728.

Kinzie, J., \& Palmer, J. (2004). "Fifty years of college choice: social, political and institutional influences on the decision making process". Indianapolis, IN: Lumina Foundation for education.

Kotler, P., \& Fox, K. (1995). "Strategic Marketing for educational institutions".

Kotler, P., \& Keller, K. (2012). Marketing management, 14 edition Prentice Hall.

Kusumawati, A. (2013). "Students "perceptions of choice criteria in the selection of an Indonesian public university" DissertationManoku, E. "Factors that influence university choice of Albanian students" Europian scientific Journal (ESI) ESJ vol. 11 No.16, June 2015. 
Manoku, E. (2015). „Factors that influence university choice of Albanian students“, 11(16), European Scientific Journal, 253-270

Nicholls, J., Harris, J., Morgan, E., Clarke, K., \& Sims, D. (1995). "Marketing in higher education: the MBA experience". International Journal of Educational Management 9(2): 31-38.

Raposo, M., \& Alves, H. (2007). “A model of university choice: an exploratory reseach” MPRA Paper No.5523, posted 31 October 2007.

Shanka, T., \& Quintal, V., \& Taylor, R. (2005). Factors Influencing International Students' Choice of an Education Destination - A Correspondence Analysis, Journal of Marketing for Higher Education, 15, 2, 31 - 46.

Sshuller, D., \& Rasticova, M. (2011). "Marketing communications mix of universities - communication with students in an increasing competitive university environment," Journal of competitiveness.

Steele, S. L. (2008). "Examining the inclination of students to apply to a postsecondary institution in their senior year of high school' Doctorial dissertation, Vanderbilt University, Nashville, Tennesse.

Veloutsou, C. (2005). "Consultation and the reliability of information sources pertaining to university selection". International Journal of Educational Management. 19(4): 279 -91.

Yamamato, G. T. (2006). “University evaluation - selection: a Turkish case”. International Journal of Educational Management, 20(7), 559-69. 